\title{
Microcystin-LR biodegradation by Sphingopyxis sp. USTB-05
}

\author{
Chengbin XIAO' ${ }^{1}$, Hai YAN $(\bowtie)^{2}$, Junfeng WANG ${ }^{2}$, Wei WEI ${ }^{2}$, Jun NING ${ }^{1}$, Gang PAN ${ }^{1}$ \\ 1 Research Center for Eco-Environmental Sciences, Chinese Academy of Sciences, Beijing 100085, China \\ 2 School of Chemical and Biological Engineering, University of Science and Technology Beijing, Beijing 100083, China
}

(C) Higher Education Press and Springer-Verlag Berlin Heidelberg 2010

\begin{abstract}
A promising bacterial strain for biodegrading microcystin-LR (MC-LR) as the sole carbon and nitrogen source was successfully isolated from Lake Dianchi, China. The strain was identified as Sphingopyxis sp. USTB-05, which was the first isolated MCs-biodegrading Sphingopyxis sp. in China. The average biodegradation rate of MC-LR by Sphingopyxis sp. USTB-05 was 28.8 $\mathrm{mg} \cdot \mathrm{L}^{-1}$ per day, which was apparently higher than those of other bacteria reported so far. The optimal temperature and $\mathrm{pH}$ for both strain USTB-05 growth and MC-LR biodegradation were $30^{\circ} \mathrm{C}$ and 7.0 , respectively. The release of MC-LR from the cyanobacterial cells collected from Lake Guishui and the biodegradation of MC-LR by both strain and cell-free extract (CE) were investigated. The results indicated that MC-LR with the initial concentration of $4.0 \mathrm{mg} \cdot \mathrm{L}^{-1}$ in water was biodegraded by Sphingopyxis sp. USTB-05 within $4 \mathrm{~d}$, while MC-LR with the initial concentration of $28.8 \mathrm{mg} \cdot \mathrm{L}^{-1}$ could be completely removed in $3 \mathrm{~h}$ by CE of Sphingopyxis sp. USTB05 containing $350 \mathrm{mg} \cdot \mathrm{L}^{-1}$ protein. During enzymatic biodegradation of MC-LR, two intermediate metabolites and a dead-end product were observed on an HPLC chromatogram. Moreover, the similar scanning profiles of MC-LR and its metabolic products indicate that the Adda side-chain of MC-LR was kept intact in all products.
\end{abstract}

Keywords microcystin-LR(MC-LR), biodegradation, Sphingopyxis sp, USTB-05, cell-free extract

\section{Introduction}

With the increase in the discharge of wastewater containing high nitrogen and phosphorus into rivers and lakes, harmful cyanobacteria blooms (HCB) have become a growing environmental problem in the world [1-3]. The ratios of eutrophic lakes are 53\%, 28\%, 48\%, and $41 \%$ in

Received November 25, 2009; accepted November 1, 2010

E-mail: haiyan@ustb.edu.cn
Europe, Africa, North America, and South America and increase to $54 \%$ and $80 \%$ in the Asian-Pacific region and China [4], respectively. HCB not only destroy the natural ecological system of lakes and rivers but also produce many types of cyanobacteria toxins of which microcystins (MCs) are the most dangerous [5]. In previous studies, we found that HCB in Lake Dianchi in Yunnan Province of China could produce a large amount of MCs [6], and MCs were also detected in Lake Guishui in Beijing, China. MCs are usually retained in algal cells during the growth, but these intracellular toxins are eventually released into water bodies, which can cause severe health risks to animals and humans.

MCs are a group of monocyclic heptapeptide hepatotoxins produced by species of cyanobacteria including Microcystis, Anabaena, Nostoc, and Oscillatoria [7,8]. More than 60 different analogues of MCs have been isolated from natural blooms or laboratory cultures of cyanobacteria [9] in which the most common and toxic analog is microcystin-LR (MC-LR) [10-13]. (2S,3S,8S,9S)-3-amino-9-methoxy-2,4,6-trimethyl-10phenyldeca-4,6-dienoic dienoic acid (Adda) as one of the constituent amino acids in MC-LR is essential for the characteristic biologic activities of MCs [14,15].

The stable cyclic structure of MCs has presented many challenges to traditional water treatment technologies [16] where conventional processes, such as adsorption [17], ozone oxidation [18], photo-degradation [14], and electrochemical oxidation [19], have limited effect on their removal [11]. Aerobic biodegradation has been considered to be the main attenuation mechanism for MCs, and this process was reported to occur in diverse ecosystems, such as rivers [12], sand filters [11], reservoirs [20,21], coastal lagoons [22], lakes [17,23,24], and sewage effluent [25]. Bacterial strains of Sphingpoyxis sp. [11], Sphingomonas sp. [8,15,20,21], Pseudomonas aeruginosa [23] Burkholderia sp. [22], and Paucibacter toxinivorans [26], isolated from Australia reservoirs, Japan lakes, a Brazilian coastal lagoon, and Finland lakes were found to have the capabilities of biodegrading MCs, respectively. Most of 
the strains reported belong to genus Sphingomonas, such as ACM-3962 [7], Y2 [8], LH21 [8], B-9 [15], 7CY [20], and CBA4 [21]. Sphingomonas sp. Y2 was reported to have the highest degradation rate of $5.4 \mathrm{mg} \cdot \mathrm{L}^{-1}$ per day for MC-LR $[8,22,24]$. On the other hand, Holst et al. [27] and Chen et al. [28] investigated the potential for anoxic biodegradation of microcystin and the effects of environmental factors on the process through a series of wellcontrolled microcosm experiments.

As to the biodegradation mechanisms for MC-LR, the previous studies focused on the biodegradation pathways of Sphingomonas sp. $[7,15,29,30]$. MC-LR is subject to microbial degradation to provide three types of products, linearized MC-LR (Adda-Glu-Mdha-Ala-Leu-MeAspArg), tetrapeptide Adda-Glu-Mdha-Ala, and Adda [7]. Further, intact nontoxic Adda was first isolated from MCLR by degradation using a B-9 strain as one of the final products [15]. In addition, Hashimoto et al. [29] identified the following MC-degrading products for cell preparation of strain B-9: a tetrapeptide, Adda-Glu-Mdha-Ala, tripeptides Adda-Glu-Mdha, Glu-Mdha-Ala, and Arg-MeAspLeu, a dipeptide, Glu-Mdha, and amino acids Adda, Arg, and methylamine derived from Mdha. However, less information is provided on the biodegradation and pathway of MC-LR directly released from the cyanobacterial cells by Sphingopyxis sp.

In this study, we isolated a bacterial strain Sphingopyxis sp. USTB-05 from Lake Dianchi, which showed a stronger capability to biodegrade MC-LR than those of other isolated bacterial strains reported previously. Rapid biodegradation was found for MC-LR directly released from the cyanobacterial cells collected from Lake Guishui in China. Furthermore, two intermediate metabolites and dead-end products were observed on the HPLC chromatogram during the biodegradation of MC-LR by cell-free extract of Sphingopyxis sp. USTB-05, which is very important from the standpoint of both basic research and its application in the efficient removal of MCs from the source of drinking water.

\section{Materials and methods}

\subsection{Strain and chemicals}

A bacterial strain used in this study for the biodegradation of MC-LR was isolated from the sediment of Lake Dianchi in China using MC-LR as the sole carbon and nitrogen sources. Standard MC-LR with a purity of $95 \%$ was purchased from Sigma Chemical, Co, and all other chemicals used were of analytical grade. The cyanobacterial cells collected from the surface of Lake Guishui on July 15,2009 , were prepared in $50 \mathrm{mM}$ PB solution ( $\mathrm{pH} 7.0$ ) containing wet cells of $35 \mathrm{~g} \cdot \mathrm{L}^{-1}$, and an MC-LR biodegrading bacterial strain was inoculated to investigate the release and biodegradation of MC-LR.

\subsection{Media and cultural conditions}

The basic medium for the isolation and culture of bacterium consisted of $1.0 \mathrm{~g} \mathrm{MgSO}_{4} \cdot 7 \mathrm{H}_{2} \mathrm{O}, 0.5 \mathrm{~g}$ $\mathrm{KH}_{2} \mathrm{PO}_{4}, 4.0 \mathrm{~g} \mathrm{Na}_{2} \mathrm{HPO}_{4} \cdot 12 \mathrm{H}_{2} \mathrm{O}, 20 \mathrm{mg} \mathrm{CaCl}_{2}, 5 \mathrm{mg}$ $\mathrm{FeSO}_{4}, 5 \mathrm{mg} \mathrm{ZnCl}, 5 \mathrm{mg} \mathrm{MnCl}_{2} \cdot 4 \mathrm{H}_{2} \mathrm{O}, 0.5 \mathrm{mg} \mathrm{CuCl} 2$, and $1000 \mathrm{~mL}$ distilled water. MC-LR with different initial concentrations was added to the medium, and the initial $\mathrm{pH}$ was adjusted to 7.0 with $1.0 \mathrm{~mol} \cdot \mathrm{L}^{-1} \mathrm{NaOH}$ or $\mathrm{HCl}$.

The bacterium was inoculated in the sterilized medium and grown in a $50-\mathrm{mL}$ flask containing $10 \mathrm{~mL}$ of liquid medium. The culture condition was at $30^{\circ} \mathrm{C}$ with a shake rate of $200 \mathrm{rpm}$. The optical density at $680 \mathrm{~nm}\left(\mathrm{OD}_{680 \mathrm{~nm}}\right)$ was measured to represent bacterial growth.

\subsection{Isolation and identification of MC-degrading strain}

The supernatant fluid of sediments taken from Lake Dianchi was inoculated into the culture medium containing $30 \mathrm{mg} \cdot \mathrm{L}^{-1} \mathrm{MC}-\mathrm{LR}$ at $30^{\circ} \mathrm{C}$ with a shake rate of $200 \mathrm{rpm}$ for isolating MC-LR biodegrading bacterial strains. After three consecutive transfers, the cultures were diluted and spread onto solid plates. Bacterial colonies grown on the plates were picked up and inoculated into liquid medium containing MC-LR of $30 \mathrm{mg} \cdot \mathrm{L}^{-1}$ to test their biodegradation capabilities of MC-LR, respectively, which were repeated several times until a pure bacterial strain was isolated.

An isolated bacterial strain capable of biodegrading MCLR was identified by $16 \mathrm{~S}$ rDNA sequence analysis, which was selectively amplified by PCR (Eppendorf-5331) with two universal primers (Pf: 5'-AGAGTTTGATCATGGCTCAG-3'; Pr: 5'-CTACGGTTACCTTGTTACGAC-3'). PCR reactions were performed for $5 \mathrm{~min}$ at $94^{\circ} \mathrm{C}$, then cycled 30 times $\left(94^{\circ} \mathrm{C}\right.$ for $1 \mathrm{~min}$, then $50^{\circ} \mathrm{C}$ for $1 \mathrm{~min}$, and, finally, $72^{\circ} \mathrm{C}$ for $3 \mathrm{~min}$ ), and then extension reactions were carried out for $10 \mathrm{~min}$ at $72^{\circ} \mathrm{C}$. The amplified DNA was sent to the Beijing Sunbiotech, Co, in China for sequencing.

\subsection{Preparation of cell-free extract (CE)}

The bacterial cells were harvested by centrifugation at $12000 \mathrm{r} \cdot \mathrm{min}^{-1}$ for $10 \mathrm{~min}$ at $4^{\circ} \mathrm{C}$, followed by washing twice with $50 \mathrm{mM}$ potassium phosphate buffer (PB, pH 7.0). The cells were resuspended in $20 \mathrm{~mL}$ PB solution and sonicated with an output power of $400 \mathrm{~W}$ for $10 \mathrm{~min}$ at $4^{\circ} \mathrm{C}$. The cell debris was removed by centrifugation at $15000 \mathrm{rpm}$ for $20 \mathrm{~min}$, and the supernatant was saved as CE. The protein concentration of CE was determined with the Bradford method [31]. The reactions containing the mixture of CE and MC-LR in PB solution were performed at the temperature of $30^{\circ} \mathrm{C}$ with a shake rate of $200 \mathrm{rpm}$. The samples of MC-LR taken at various time points were measured by HPLC. 


\subsection{Analysis of MC-LR}

MC-LR was measured using a High Performance Liquid Chromatography (HPLC) system (Shimadzu LC-10ATVP, Shimadzu, Co, Japan) with an UltraViolet (UV) Diode Array Detector at $239 \mathrm{~nm}$ using a column of Waters $\mu$ Bondapak $\mathrm{C}_{18}(300 \times 3.9 \mathrm{~mm})$. The mobile phase was $40 \%(\mathrm{v} / \mathrm{v})$ acetonitrile-water solution containing $0.03 \%$ $(\mathrm{v} / \mathrm{v})$ of trifluoroacetic acid with flow-rate of $1.0 \mathrm{~mL} \cdot \mathrm{min}^{-1}$. The calibration curve was established between the peak areas and the concentration of MC-LR: the curve was used to calculate the unknown concentration of MC-LR in the experiments.

\section{Results and discussion}

\subsection{Isolation and identification of MC-degrading strain}

Using MC-LR as the sole carbon and nitrogen sources, an MC-LR biodegrading bacterial strain named USTB-05 was successfully isolated, which formed a circle yellow colony on solid medium (Fig. 1). The observation under a microscope indicated that the cells of strain USTB-05 were gram-negative and short-rod with Gram Stain (Fig. 2). The strain could grow in a $\mathrm{pH}$ range from 6.0 to 11.0 and also on the agar medium with a maximum $\mathrm{NaCl}$ of $2 \%$. It had no antibiotic resistance to any of the eight antibiotics including tetracycline, streptomycin, kanamycin, amphtericin, chloromycetin, gentamycin, spectinomycin, and erythromycin.

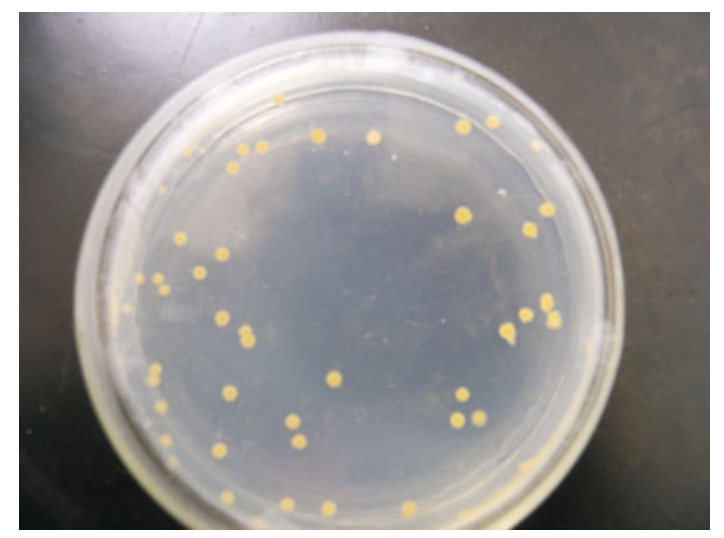

Fig. 1 Colonies of strain USTB-05 grown on solid medium

The relationship of strain USTB-05 to other closely related members is shown in Fig. 3. The analysis results of 16S rDNA sequence showed that strain USTB-05 appeared to be closely related to Sphingopyxis sp. Based on the phylogenetic analysis of $16 \mathrm{~S}$ rDNA sequences, the isolated bacterial strain was identified and named as Sphingopyxis sp. USTB-05. The complete $1453 \mathrm{bp}$ sequences of strain USTB-05 16S rDNA have been

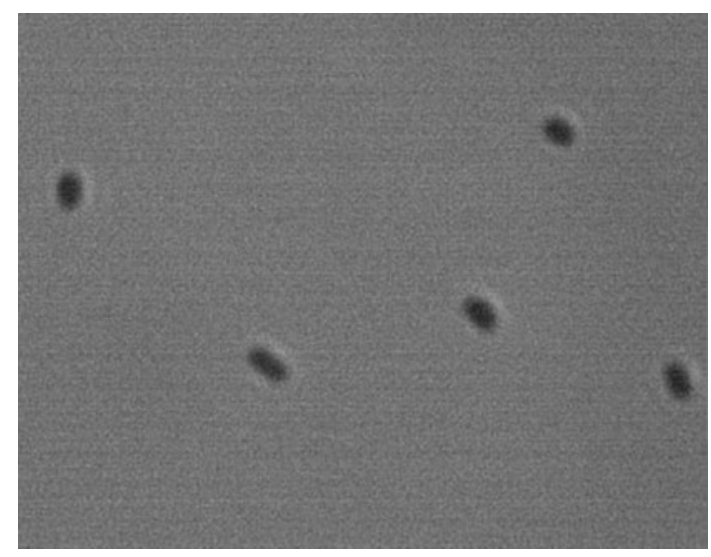

Fig. 2 Cell shape of strain USTB-05 under microscope $(\times 1000)$

deposited in the GenBank database under accession number EF607053.

\subsection{Biodegradation of MC-LR by Sphingopyxis sp. USTB-05}

At $30^{\circ} \mathrm{C}$ with a shake rate of $200 \mathrm{rpm}$, the biodegradation of MC-LR and the growth of Sphingopyxis sp. USTB-05 are shown in Fig. 4. The growth process of strain USTB-05 underwent a lag phase in the first $8 \mathrm{~h}$, exponential phase between $8 \mathrm{~h}$ to $24 \mathrm{~h}$, and stationary phase after $24 \mathrm{~h}$. With the growth of strain USTB-05, the MC-LR concentration slowly decreased from $0 \mathrm{~h}$ to $8 \mathrm{~h}$ and sharply declined from $8 \mathrm{~h}$ to $24 \mathrm{~h}$. The maximum biodegradation rate appeared at the most rapid growth phase of USTB-05, and the initial MC-LR of $28.8 \mathrm{mg} \cdot \mathrm{L}^{-1}$ was completely removed within $24 \mathrm{~h}$.

Some bacterial strains, such as Sphingpoyxis sp. [11], Sphingomonas sp. [8,15,20,21,29], and Pseudomonas aeruginosa [22] for the MCs biodegradation were successfully isolated from the surface water or sediment of HCB lakes. Sphingomonas sp. Y2 was reported to have the highest biodegradation rate of $5.4 \mathrm{mg} \cdot \mathrm{L}^{-1} \mathrm{MC}-\mathrm{LR}$ per day $[8,22,24]$. A very promising bacterial strain isolated and identified as Sphingopyxis sp. USTB-05 was the first isolated bacterial strain of Sphingopyxis capable of biodegrading MC-LR found? in China (Fig. 3). Sphingopyxis sp. USTB-05 indeed had a stronger capability to biodegrade MC-LR than those bacterial strains reported previously, and the initial MC-LR of $28.8 \mathrm{mg} \cdot \mathrm{L}^{-1}$ could be completely removed within one day (Fig. 4).

3.3 Effects of $\mathrm{pH}$ and temperature on USTB-05 growth and MC-LR biodegradation

The MC-LR biodegradation by Sphingopyxis sp. USTB-05 under the different initial $\mathrm{pHs}$ and temperatures was investigated (Fig. 5). It indicated that the MC-LR biodegradation was promoted at initial pHs of 7.0 and 9.0 but 


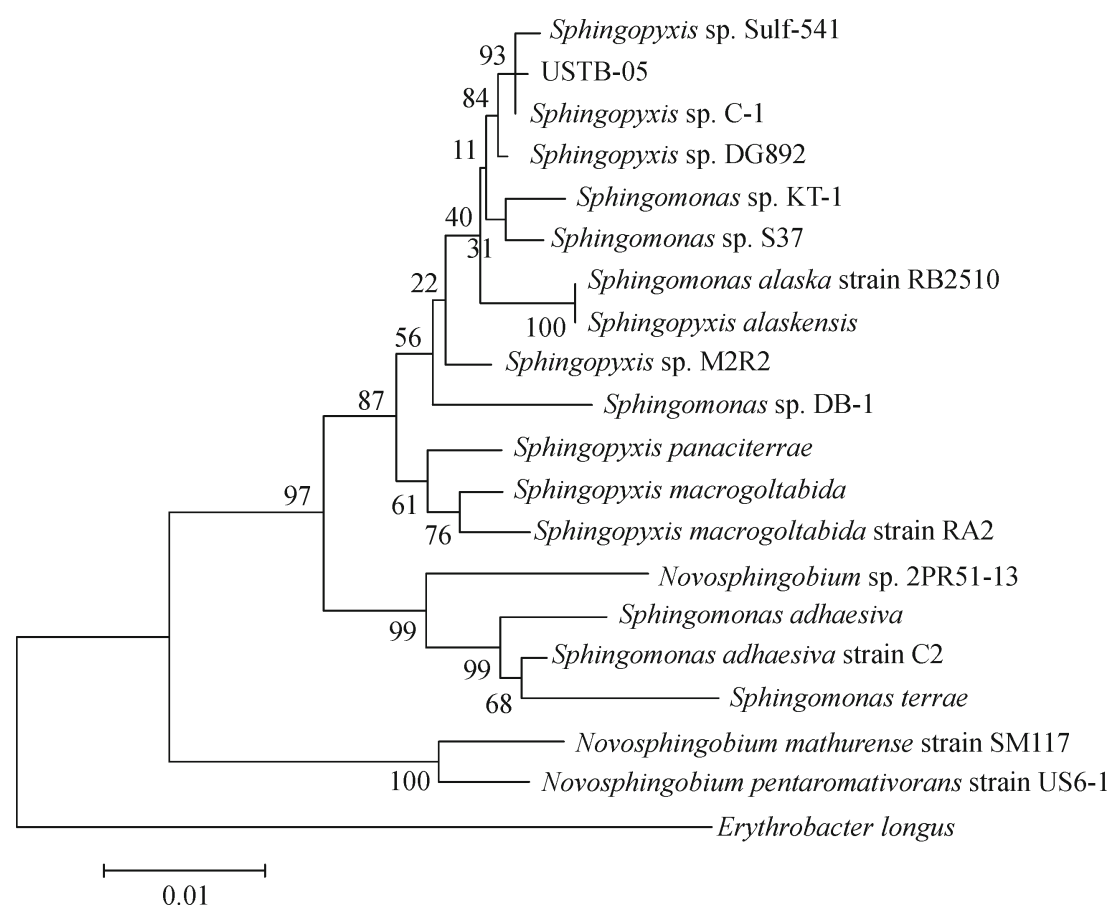

Fig. 3 Phylogenetic tree of Sphingopyxis sp. USTB-05

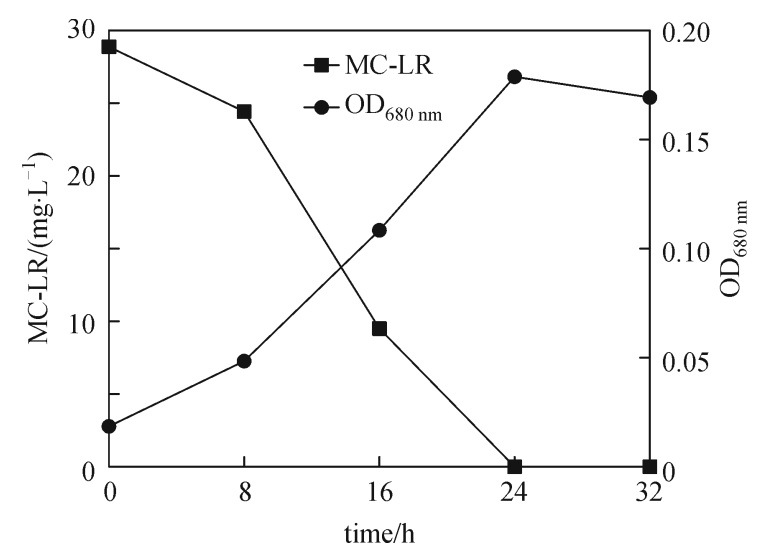

Fig. 4 Growth of Sphingopyxis sp. USTB-05 and biodegradation of MC-LR

was apparently inhibited at an initial pH of 5.0 (Fig. 5(a)). It also showed an optimal growth temperature of $30^{\circ} \mathrm{C}$ (with a range from $25^{\circ} \mathrm{C}$ to $37^{\circ} \mathrm{C}$ ) for the MC-LR biodegradation (Fig. 5 (b)). Generally, HCB appeared in an alkaline water body at $30^{\circ} \mathrm{C}$, and the isolated Sphingopyxis sp. USTB-05 was suitable to the environment of high $\mathrm{pH}$ and mesophilic temperature, so the MCLR biodegradation was significantly enhanced under the conditions of an alkaline environment and mesophilic temperature.

\subsection{Release and biodegradation of MC-LR}

Figure 6 indicates that the initial MC-LR of $4.0 \mathrm{mg} \cdot \mathrm{L}^{-1}$ increased to about $5.6 \mathrm{mg} \cdot \mathrm{L}^{-1}$ within $2 \mathrm{~d}$ and then kept stable until day 5 in the presence of cyanobacterial cells collected from Lake Guishui, which reflects the release of MC-LR from the cyanobacterial cells into water. However, in the presence of Sphingopyxis USTB-05, the MC-LR concentration decreased rapidly to nil at day 4, which indicated that Sphingopyxis USTB-05 can quickly remove MC-LR presented in water initially and that released from cyanobacterial cells within $4 \mathrm{~d}$. This is very important in the efficient removal of MC-LR from water.

\subsection{Biodegradation of MC-LR by CE of Sphingopyxis sp. USTB-05}

Figure 7 shows the MC-LR biodegradation rates by the crude enzymes of Sphingopyxis sp. USTB-05 containing protein concentrations of 70,210 , and $350 \mathrm{mg} \cdot \mathrm{L}^{-1}$, respectively, which were much higher than that by Sphingopyxis sp. USTB-05 cells (Fig. 4), resulting in the initial MC-LR of $28.8 \mathrm{mg} \cdot \mathrm{L}^{-1}$ being completely eliminated within 12,5 , and $3 \mathrm{~h}$, respectively. MC-LR could be biodegraded by both cells and CE of Sphingopyxis sp. USTB-05, which is in agreement with the earlier reports by Bourne et al. [7] and Ishii et al. [30]. The results suggested that the $\mathrm{CE}$ of MC-biodegrading bacterium is also valuable to efficiently eliminate MC-LR from drinking water.

In the presence of $\mathrm{CE}$ containing $70 \mathrm{mg} \cdot \mathrm{L}^{-1}$ protein and $28.8 \mathrm{mg} \cdot \mathrm{L}^{-1} \mathrm{MC}-\mathrm{LR}$, the MC-LR biodegradation products were further investigated using HPLC profiles over time (Fig. 8). The retention time of the MC-LR peak was $10.1 \mathrm{~min}$ (Fig. 8(a)). After reaction for $90 \mathrm{~min}$, the peak of 


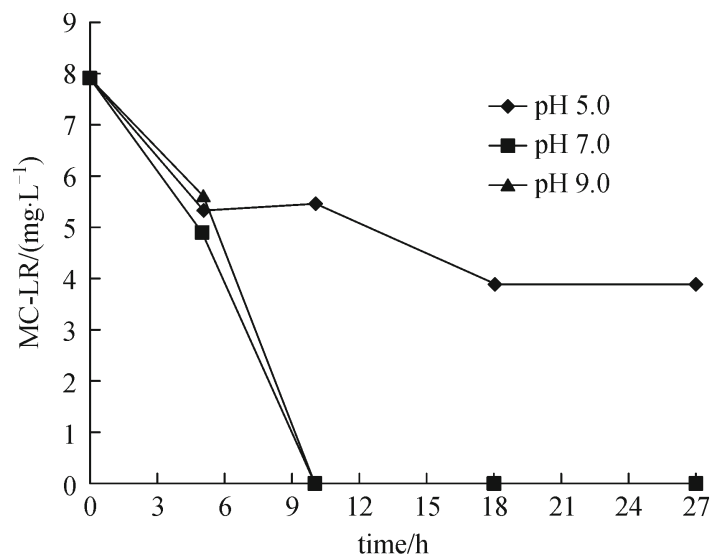

(a)

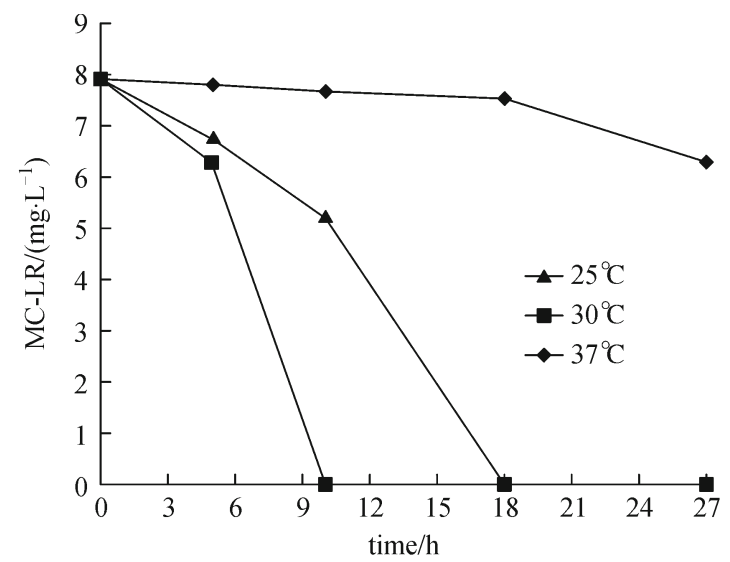

(b)

Fig. 5 Effects of $\mathrm{pH}$ (a) and temperature (b) on the biodegradation of MC-LR

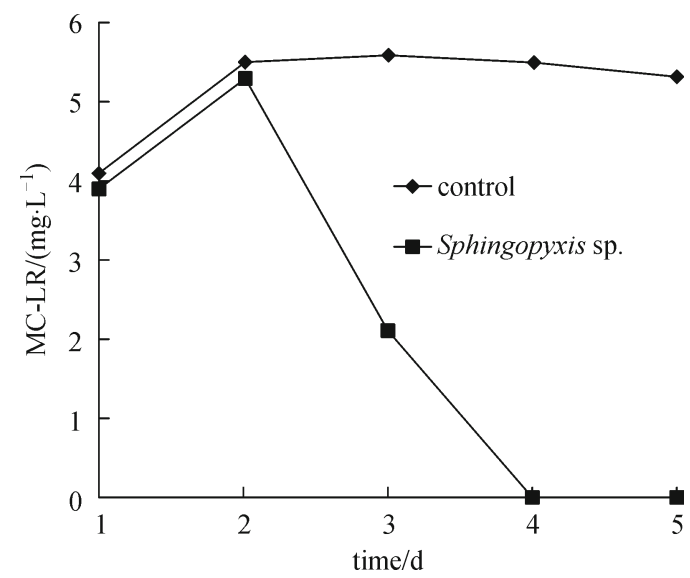

Fig. 6 Biodegradation of MC-LR remained in water and released from cyanobacterial cells collected from Lake Guishui by Sphingopyxis sp. USTB-05

MC-LR decreased and three peaks of products A, B, and C at retention times $3.6 \mathrm{~min}, 6.1 \mathrm{~min}$, and $8.6 \mathrm{~min}$ appeared, respectively (Fig. 8(b)). The peaks of MC-LR and product A decreased, while those of product $\mathrm{B}$ and $\mathrm{C}$ increased at 180 min, (Fig. 8(c)). At the time of 720 min, only peak C could be observed, while all the peaks of MC-LR and the products of A and B disappeared (Fig. 8(d)). This showed that at least three products were produced during the biodegradation of MC-LR catalyzed by the enzymes of Sphingopyxis USTB-05; the products of A and B were intermediate products, and product $\mathrm{C}$ was a final biodegradation product.

Bourne et al. [7] and Haradi et al. [15] found that linear MC-LR and a tetrapeptide ( $\mathrm{NH}_{2}$-Adda-Glu-Mdha-Ala$\mathrm{OH})$ were the first and second products of MC-LR biodegradation catalyzed by the enzymes of Sphingomonas sp. and Sphingomonas sp. B-9, respectively. However, Haradi et al. [15] reported that Adda was one of the final products of MC-LR biodegradation by another

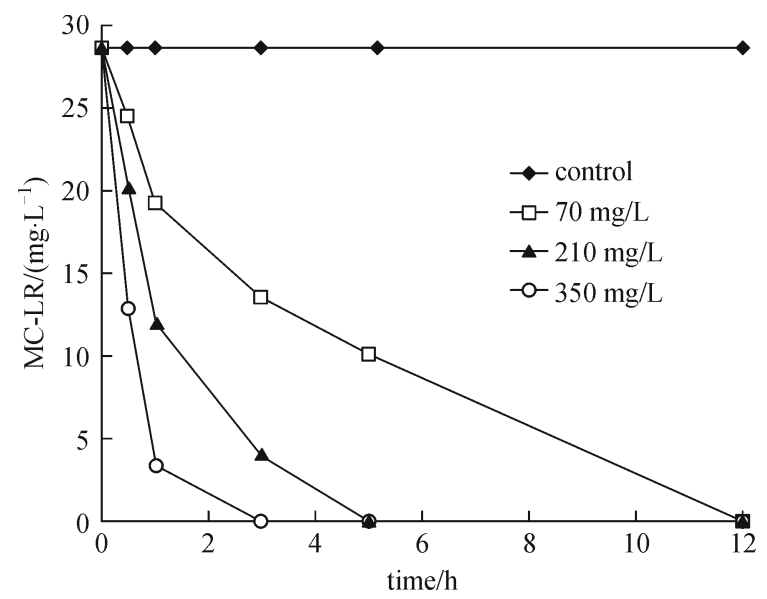

Fig. 7 Biodegradation of MC-LR by CE of Sphingopyxis sp. USTB-05 with different protein concentrations

Sphingomonas sp. isolated. Furthermore, Hiroshi et al. [30] observed three products from the biodegradation of MC-LR by Sphingomonas sp.7CY, which indicated that the biodegradation pathways of MC-LR by various bacterial strains might be different. Here, we found two intermediates and one dead-end product clearly on the HPLC profile (Fig. 8), which is very important in the further study of the biodegradation pathway of MC-LR.

The 4, 6-conjugated diene of Adda amino acid side chain in MCs contributed to the characteristic spectrum and was an important determinant of MC-LR in HPLC analysis [7]. MC-LR showed a $\lambda_{\max }$ of $239 \mathrm{~nm}$, while the $\lambda_{\max }$ of products A, B, and C were all at or near $239 \mathrm{~nm}$ (Fig. 9); moreover, the UV spectra of all products were very similar to that of MC-LR. This indicates that the Adda side-chain was kept intact following enzymatic modification of MC-LR by CE of Sphingopyxis sp. USTB-05. The biodegradation pathway of MC-LR by Sphingopyxis sp. USTB-05 is being studied now. 

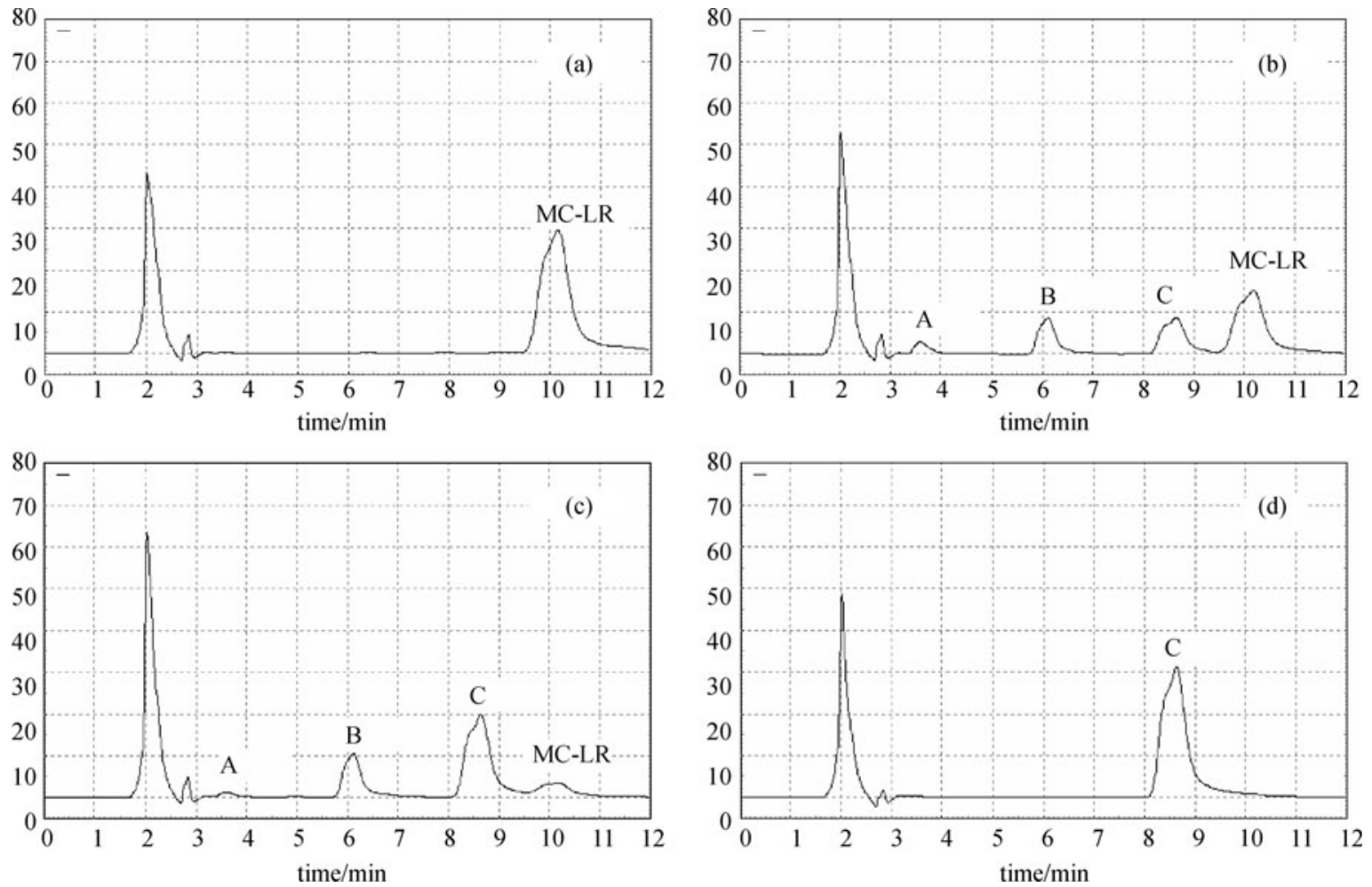

Fig. 8 HPLC profiles for biodegrading MC-LR by CE of Sphingopyxis sp. USTB-05 with time course. (a) 0 min; (b) 90 min; (c) $180 \mathrm{~min}$; (d) $720 \mathrm{~min}$

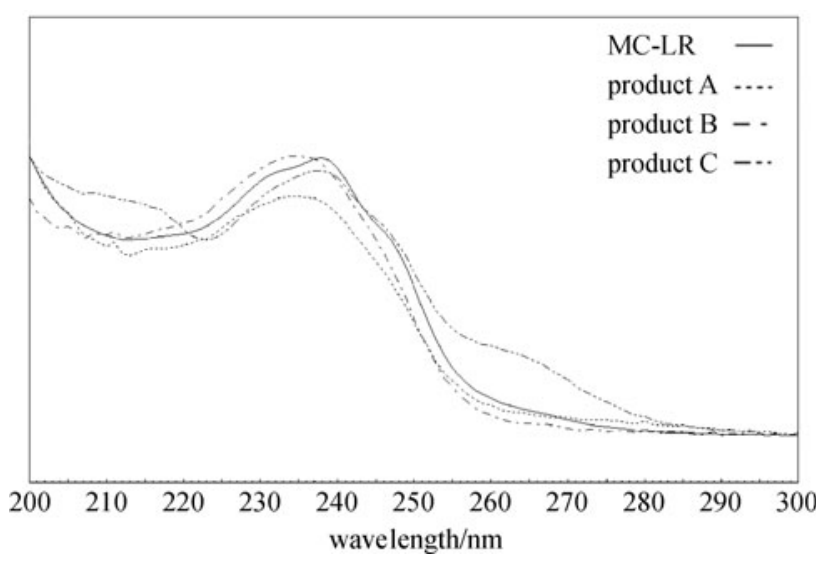

Fig. 9 Absorbance profiles of MC-LR and its biodegradation products in the ultraviolet wavelength from 200 to $300 \mathrm{~nm}$, respectively

\section{Conclusions}

Sphingopyxis sp. USTB-05 is a MCs-biodegrading strain isolated from the sediment of Lake Dianchi, China. The initial MC-LR of $28.8 \mathrm{mg} \cdot \mathrm{L}^{-1}$ could be completely biodegraded within $24 \mathrm{~h}$. The optimal temperature and $\mathrm{pH}$ for the $\mathrm{MC}-\mathrm{LR}$ biodegradation are $30^{\circ} \mathrm{C}$ and 7.0 , respectively. Furthermore, the initial MC-LR of $28.8 \mathrm{mg} \cdot \mathrm{L}^{-1}$ could be completely removed at $3 \mathrm{~h}$ by its $\mathrm{CE}$ containing
$350 \mathrm{mg} \cdot \mathrm{L}^{-1}$ protein. Initial $\mathrm{MC}-\mathrm{LR}$ of $4.0 \mathrm{mg} \cdot \mathrm{L}^{-1}$ in water, which was produced by the cyanobacterial cells collected from Lake Guishui, was totally eliminated by Sphingopyxis sp. USTB-05 within $4 \mathrm{~d}$. During the biodegradation of MC-LR catalyzed by crude enzymes, two intermediate and a dead-end products of MC-LR had been observed on a HPLC chromatogram. The similar scanning profiles of MC-LR and its metabolic products at the ultraviolet wavelength from 200 to $300 \mathrm{~nm}$ indicated that the group of Adda in MCs was kept intact, which is very important for the efficient removal of MC-LR from the drinking water source.

Acknowledgements The first and second authors did same contribution to this paper. This work was supported by the National Natural Science Foundation of China (Grant No. 203777008), State Key Joint Laboratory of Environment Simulation and Pollution Control (No. 09K08ESPCT), and Educational Committee of Beijing.

\section{References}

1. Dawson R M. The toxicology of microcystins. Toxicon, 1998, 36 (7): 953-962

2. Kaebernick M, Neilan B A. Ecological and molecular investigations of cyanotoxin production. FEMS Microbiology Ecology, 2001, 35 (1): $1-9$

3. Haider S, Naithani V, Viswanathan P N, Kakkar P. Cyanobacterial 
toxins: a growing environmental concern. Chemosphere, 2003, 52 (1): $1-21$

4. Zhang W H, Xu X Q, Qiu C Q. Advance in study on microcystins in aquatic environment.Research of Environmental Sciences, 2001, 14 (2): 57-61 (in Chinese)

5. Duy T N, Lam P K S, Shaw G R, Connell D W. Toxicology and risk assessment of freshwater cyanobacterial (blue-green algal) toxins in water. Reviews of Environmental Contamination and Toxicology, 2000, 163: 113-185

6. Yan H, Pan G, Zou H, Li X L, Chen H. Effective removal of microcystins using carbon nanotubes embedded with bacteria. Chinese Science Bulletin, 2004, 49(16): 1694-1698

7. Bourne D G, Jones G J, Blakeley R L, Jones A, Negri A P, Riddles P. Enzymatic pathway for the bacterial degradation of the cyanobacterial cyclic peptide toxin microcystin LR. Applied and Environmental Microbiology, 1996, 62(11): 4086-4094

8. Ho L, Gaudieux A L, Fanok S, Newcombe G, Humpage A R. Bacterial degradation of microcystin toxins in drinking water eliminates their toxicity. Toxicon, 2007, 50(3): 438-441

9. Qiao R P, Li N, Qi X H, Wang Q S, Zhuang Y Y. Degradation of microcystin-RR by UV radiation in the presence of hydrogen peroxide. Toxicon, 2005, 45(6): 745-752

10. Cousins I T, Bealing D J, James H A, Sutton A. Biodegradation of microcystin-LR by indigenous mixed bacterial populations. Water Research, 1996, 30(2): 481-485

11. Ho L, Meyn T, Keegan A, Hoefel D, Brookes J, Saint C P, Newcombe G. Bacterial degradation of microcystin toxins within a biologically active sand filter. Water Research, 2006, 40(4): 768774

12. Bourne D G, Blakeley R L, Riddles P, Jones G J. Biodegradation of the cyanobacterial toxin microcystin LR in natural water and biologically active slow sand filters. Water Research, 2006, 40(6): 1294-1302

13. Zhang J B, Zheng Z, Yang G J, Zhao Y F. Degradation of microcystin by gamma irradiation. Nuclear Instruments \& Methods in Physics Research. Section A, Accelerators, Spectrometers, Detectors and Associated Equipment, 2007, 580(1): 687-689

14. Welker M, Steinberg C. Rates of humic substance photosensitized degradation of microcystin-LR in natural waters. Environmental Science \& Technology, 2000, 34(16): 3415-3419

15. Harada K, Imanishi S, Kato H, Mizuno M, Ito E, Tsuji K. Isolation of Adda from microcystin-LR by microbial degradation. Toxicon, 2004, 44(1): 107-109

16. Falconer I R. An overview of problems caused by toxic blue-green algae (cyanobacteria) in drinking and recreational water. Environmental Toxicology, 1999, 14(1): 5-12

17. Yan H, Gong A J, He H S, Zhou J, Wei Y, Lv L. Adsorption of microcystins by carbon nanotubes. Chemosphere, 2006, 62(1): 142148
18. Svrcek C, Smith D W. Cyanobacteria toxins and the current state of knowledge on water treatment options: a review. Journal of Environmental Engineering and Science, 2004, 3(3): 155-185

19. Feng C, Sugiura N, Masaoka Y, Maekawa T. Electrochemical Degradation of Microcystin-LR. J Environ Sci Health, Part A: Tox Hazard Subst Environ Eng. 2005, 40(2): 453-465

20. Jones G J, Bourne D G, Blakeley R L, Doelle H. Degradation of the cyanobacterial hepatotoxin microcystin by aquatic bacteria. Natural Toxins, 1994, 2(4): 228-235

21. Valeria A M, Ricardo E J, Stephan P, Alberto W D. Degradation of Microcystin-RR by Sphingomonas sp. CBA4 isolated from San Roque reservoir (Córdoba- Argentina). Biodegradation, 2006, 17 (5): 447-455

22. Lemes G A F, Kersanach R, Pinto Lda S, Dellagostin O A, Yunes J $\mathrm{S}$, Matthiensen A. Biodegradation of microcystins by aquatic Burkholderia sp. from a South Brazilian coastal lagoon. Ecotoxicology and Environmental Safety, 2008, 69(3): 358-365

23. Takenaka S, Watanabe M F. Microcystin LR degradation by Pseudomonas aeruginosa alkaline protease. Chemosphere, 1997, 34 (4): 749-757

24. Park H D, Sasaki Y, Maruyama T, Yanagisawa E, Hiraishi A, Kato K. Degradation of the cyanobacterial hepatotoxin microcystin by a new bacterium isolated from a hypertrophic lake. Environmental Toxicology, 2001, 16(4): 337-343

25. Lam A K Y, Fedorak P M, Prepas E E. Biotransformation of the cyanobacterial hepatotoxin microcystin-LR, as determined by HPLC and protein phosphatase bioassay. Environmental Science \& Technology, 1995, 29(1): 242-246

26. Edwards C, Graham D, Fowler N, Lawton L A. Biodegradation of microcystins and nodularin in freshwaters. Chemosphere, 2008, 73 (8): 1315-1321

27. Holst T, Jørgensen N O G, Jørgensen C, Johansen A. Degradation of microcystin in sediments at oxic and anoxic, denitrifying conditions. Water Research, 2003, 37(19): 4748-4760

28. Chen X G, Yang X, Yang L, Xiao B, Wu X, Wang J, Wan H. An effective pathway for the removal of microcystin LR via anoxic biodegradation in lake sediments. Water Research, 2010, 44(6): 1884-1892

29. Hashimoto E H, Kato H, Kawasaki Y, Nozawa Y, Tsuji K, Hirooka E Y, Harada K. Further investigation of microbial degradation of microcystin using the advanced Marfey method. Chemical Research in Toxicology, 2009, 22(2): 391-398

30. Ishii $H$, Nishijima $M$, Abe T. Characterization of degradation process of cyanobacterial hepatotoxins by a gram-negative aerobic bacterium. Water Research, 2004, 38(11): 2667-2676

31. Bradford M M. A rapid and sensitive method for the quantitation of microgram quantities of protein utilizing the principle of protein-dye binding. Analytical Biochemistry, 1976, 72(1-2): 248-254 